\title{
Health with equality: a proposal for the incorporation of the gender perspective in health care systems
}

Maria Luisa Panisello ${ }^{1}$ Inma Pastor ${ }^{2}$
${ }^{1}$ Grupo Investigación Enfermeria Avanzada SGR 030, Facultad Enfermeria, Universidad Rovira i Virgili. Avinguda Remolins 13-15. 43590 Tortosa Catalonia Spain.

marisa.panisello@urv.cat ${ }^{2}$ Social and Business Research laboratory, Departamento de Gestión de Empresas, Universidad Rovira i Virgili.

\begin{abstract}
This paper presents an analysis of the incorporation of the gender perspective in health care-related policies. Based on the recommendations of international organizations, the importance of the incorporation of the gender concept in the health field is analyzed, in order to design health policies that seeking to redress existing inequalities by virtue of sex/gender. This paper presents an analysis of the published guidelines in order to facilitate the incorporation of the gender perspective in health care systems. The article concludes with a proposal of gender-sensitive health indicators that can ensure the gender perspective in health care policies.

Key words Gender perspective, Health care systems, Socieconomic factors, Equality policies, Health care policies
\end{abstract}




\section{Introduction}

Health systems are created to meet the health needs of communities, and are the result of a long historical development and various factors that are part of the social system. Health is a complex process determined by the interplay of individuals' biological, psychological and social factors and environmental factors. Since the 1990s, several studies ${ }^{1-4}$ have shown that women and men become ill in different ways and metabolize drugs differently, and have different lifestyles related to health problems. The main contribution of these studies is to show that gender, along with other dimensions such as social class, is a determinant in the health-disease process, and creates inequalities that take the form of access to hospitals, waiting lists and therapeutic strategies ${ }^{5,6}$. These factors are involved in health and healthcare, and lead to differences and inequalities based on sex/gender in health and in healthcare.

According to the World Health Organization (WHO), the concept of health inequality refers to the different opportunities and resources related to health that individuals have depending on their social class, gender, territory or ethnicity; these opportunities and resources are associated with a poor state of health among underprivileged groups. The WHO argues that these differences in health are unnecessary, avoidable and unfair?

These differences and inequalities can be changed by health and social policies. In this article, based on the recommendations of international organizations, we analyze the importance of introducing the concept of gender in the health sphere in order to design public policies to redress the existing inequalities. We analyze the guidelines published for this incorporation up to 2008 as instruments for guidance in this process. We conclude the article with proposals that can ensure the inclusion of the gender perspective in health policies.

According to Sen et al. ${ }^{8}$, an approach to health with a gender perspective, i.e. one which distinguishes between biological and social factors while examining how they interact and taking into account how inequality affects health experiences, provides guidance for identifying the appropriate responses by the healthcare system and public policy.

Given this reality, international agencies and governments are concerned to introduce the gen- der perspective in health policies. The overall objective of these policies is to address the inequalities that arise from the different roles of women and men, as well as the unequal power relations between them, and the consequences of those inequalities for their lives, health and welfare.

The United Nations (UN) Fourth World Conference ${ }^{9}$ on Women held in Beijing in 1995 set out the guidelines for all government action, analyzing the effects of all policies and programmes from the point of view of gender. In 2002, the World Health Organization $(\mathrm{WHO})^{10}$ produced a policy document on gender: Integrating gender perspectives in the work of WHO. In the introductory statement, Gro Harlem Brundtland, who was the organization's Director-General at the time, said that integrating gender perspectives in health action is sound public health. According to the document, the Organization's policy will be to ensure that all research, policies, programmes, projects, and initiatives with WHO involvement address gender issues. Its goals and objectives include:

- To promote equity and equality between women and men, throughout the lifecourse.

- To provide qualitative and quantitative information on the influence of gender on health and health care.

- To promote the integration of gender issues in health systems.

The Millennium Declaration of the United Nations ${ }^{11}$ and other international agreements acknowledge the importance of equal rights for men and women and the rights of all to live free from discrimination in any sphere of life, including access to health care.

Public policies with a gender perspective are processes through which public policy initiatives seeking to redress the inequality generated in the gender system by promoting equity between men and women are developed and implemented ${ }^{12}$. According to Astelara ${ }^{13}$, the relationship between gender and politics must be taken into account, i.e. policy is determined by the gender system as it is a predominantly male activity. The gender system is also maintained and reproduced by political intervention, since each initiative by the State may have a different impact on the situation of men and women and create situations, albeit indirectly, that impair gender equality. Based on these considerations, it is therefore necessary to introduce the gender dimension in all activities by State institutions. 


\section{On the relationship of the sex/gender system to health and disease}

When considering gender in relation to equality policies within the health system we must describe the relationship of the sex/gender system to health and its problems. We have already mentioned that there have been various initiatives, studies and publications since the 1990s for the consolidation of scientific knowledge on the relationship between sex/gender and health.

One such initiative was undertaken by the international networks who met in various forums worldwide in 1990. Barcelona hosted the First International Symposium on Women and Quality of Life, organized by CAPS, Women's Health Meeting in Boston ${ }^{1}$. In 1991, Women's Health was included in the Index Medicus, which is considered the most comprehensive index of articles from scientific and medical journals published in the United States since 1879. Also in 1991, Dr Healy ${ }^{14}$, with the publication of the article "The Yentl syndrome" in the New England Journal of Medicine, highlighted the malpractice of Americans cardiology services due to their failure to perform the same diagnostic techniques and examinations for women as for men. That analysis showed that many more coronariographies were performed on men than on women, and that women were systematically excluded from clinical trials.

All these women's movements were of crucial importance due to being the beginning and the reference point in the construction of knowledge about the influence of gender on health and its problems. In the editorial of The New England Journal of Medicine of July 1993, Marcia Angell analyzed discrimination against women in medical research and highlighted discrimination in three areas:

1. Women's diseases have been studied to a lesser extent.

2. Women are less likely to be included as participants in clinical trials.

3. Women are unlikely to be able to become research directors to conduct clinical trials ${ }^{15}$.

These research lines were developed based on the formulation and development of gender theory. This theory considered the influence of sex/ gender to be an explanatory factor in health.
The roots of gender theory lie in ethnographic descriptions and observations of other cultures, which revealed societies with more than two genders. There was shown to be a diversity of content in terms of what is considered male and female in different cultures and eras. This discovery helped to deconstruct the supposedly natural character of the masculine and feminine identities. The background to gender theory lies in the anthropological studies by Margaret Mead and Simone de Beauvoir's The Second Sex, with the statement: "One is not born, but rather becomes, a woman." The discovery of the varying abilities and aptitudes attributed to women and men from one society to another, and from one era to another, meant that these skills and aptitudes were not established by biology, but were instead socially determined. This approach revolutionizes traditional ideas about the subject, because it frees men and women from biological determinism and opens up new possibilities for social identity ${ }^{16}$. This conceptual system (sex/ gender) questioned the alleged biological basis of male and female behaviours and states that gender is a social construct, i.e. that what is understood to be a man or a woman is not a set of anatomical details, but instead social and cultural constructions with an ambiguous and unstable biological basis ${ }^{17}$.

For Marina Subirats, the theory of sex/gender introduces these two terms to facilitate the distinction between biological facts and social facts. It is indisputable that there are differences between men and women from a biological point of view. However, it has not been demonstrated that these biological differences, for which the term "sex" is used, implicitly entail differences in abilities, aptitudes and attitudes between individuals. What creates different abilities, behaviours and personalities is gender: gender is the differentiated set of rules for each sex, which each society creates according to its needs and which are imposed on individuals from birth, as patterns that govern their entire behaviour, desires and actions. Genders are continuously redefined by society, are never completely stable, and change in relation to other social changes, such as the division of labour, sexual morality, demographic changes, including wars ${ }^{16}$. 


\section{Gender and health: two concepts in continuous interaction}

As mentioned above, health is a complex process determined by the interplay of biological, psychological and social factors. According to Rohlfs et al. ${ }^{4}$, the variables to consider when designing health surveys in order to facilitate analysis of health and its problems from the gender perspective are those shown in Chart 1.

We consider some of these variables in terms of their importance to health and its problems below. Marital status or domestic partnership has a different effect on health depending on gender. For men, it is a protective factor and for women, due to the unequal distribution of housework, it entails an increase in reproductive work and may contribute to deterioration in health ${ }^{4}$.

Chart 1. Variables that enable analysis from a gender perspective.

1. Socio-demographic and employment variables
- Marital status
- Social class
- Level of education
- Employment situation
- Productive work (paid)
$\quad$ Occupation or place of work
Type of contract
Type of shift
Weekly working hours
2. Reproductive work (unpaid)
- Family structure (cohabitation): age, sex,
relationship between the people living together
- Domestic work
- Carrying out domestic work: doing the shopping,
cooking, cleaning, ironing...
- Sharing of domestic work
- Care for dependents (children, elderly people,
disabled)
- Sharing of care work
- Availability of external help (from family
members or from paid assistance) for domestic and
care work
- Hours spent on reproductive work
3. Morbidity, perceived health, quality of life and
mental health. Chronic disorders.
4. Social support (presence and type of social
network). Functional social support (affective and
confidential)

Source: Rohlfs et al. ${ }^{4}$.
Social class is one of the most important determinant factors in health. In our society, women are more vulnerable to poverty and social exclusion. It is essential to analyze how gender is associated with individual socioeconomic and family circumstances, so that as environmental conditions deteriorate, health indicators become more negative. For this reason, it is important to study how conditions in the social environment, working conditions (productive and reproductive) and lifestyle affect individuals' health, as well as to highlight the points at which the determinants are different depending on sex, and to review the health of a society that is deeply unequal as regards gender ${ }^{4}$.

For Borrell et al. ${ }^{18}$, few studies have analyzed health inequalities taking into account different measures of social class for women. Women are assumed to belong to their husband's or the head of the family's social class. According to Borell, there are various indicators for assigning social class to women:

- Conventional social class, which attributes women's social class based on the occupation of the husband or the head of household.

- Individual social class, which uses women's social class based on their own occupation.

- The dominant class, which is based on attributing social class based on the most privileged occupation in the household.

The influence of work on health has been widely evidenced; numerous studies highlight the influence of working conditions on health and the difference in distribution by gender. Men tend to have a job that requires more physical exertion, and women are often more exposed to psychosocial risk factors ${ }^{19}$. Studies of the employed population aged 25-64 years old, married or living with a partner, show the negative impact of the double working day on various health indicators in women, but no association is found among men ${ }^{20,21}$.

Various authors ${ }^{22,23}$ suggest that there are two types of segregation on gender grounds in productive or paid work. These are horizontal segregation, i.e. difficulty in accessing certain jobs classified as being for a specific sex, and vertical segregation, or the glass ceiling, which is the term used to describe an invisible upper threshold in women's careers that is difficult to cross, which prevents further progress. Their invisibility is due to the fact that there are no laws or established social mechanisms or visible codes imposing this 
limitation on women, but they are instead based on other factors that are difficult to identify.

Carrasquer et $\mathrm{al} .^{24}$ define reproductive work as household activities, which may be work aimed at ensuring the biological, social and ideological reproduction of the labour force, as distinct from productive work (the production of goods and services). Reproductive work is considered part of women's role and suffers from a significant lack of recognition. It mainly involves monotonous and repetitive tasks, which in some cases amount to a double workload ${ }^{24}$. The demands of housework have a negative impact on women's health, but not on men's health. There is an imbalance between women and men in terms of the time spent on reproductive work ${ }^{25}$. Rolhlfs et al. emphasize that for women, "living together" invariably means "caring" - not only for children, but for everyone in the household ${ }^{4}$.

The level of services for families is low, and the overload of responsibilities (on women in particular) is high. The limited nature of public services helping families creates an overload on Spanish women as they care for children, young people, their husbands or partners, and for the elderly and disabled ${ }^{26}$. For women, their role as caregivers often means they have to ask for leave from work or seek part-time employment. According to the 2012 statistical bulletin "Mujeres en cifras" ["Women in figures"], people employed on a part-time basis had that kind of work day because they also cared for family members who were young, sick, disabled or elderly. $97.23 \%$ of those in part-time work for those reasons were women (287,900 in absolute terms), and 59.05\% of those women stated that they had a part-time job because of the lack of adequate services providing care for the people mentioned or because they were unable to afford them ${ }^{27}$.

In a study of 100 main caregivers of elderly people with dementia, 86 were women. Another person over 65 years old lived in 51 households ${ }^{28}$. According to figures from the Senior Citizens Observatory (IMSERSO), cited by Navarro and Quiroga ${ }^{26}$, there is a pattern of care that is defined by the sex of the dependent individuals. Dependent elderly women are cared for primarily by their daughters. Dependent elderly men are cared for by their wives or daughters. "The model of care for disabled older people is based on women, wives or daughters, caring for men - husbands or fathers. Most care is provided by middle-aged women (40-65 years old). Worryingly, nearly
$12 \%$ of caregivers (mainly women) are over 70 years old $^{26}$. In a Spain-wide cross-sectional epidemiological study by the Survey on Disability, Personal Autonomy and Dependence in 2008, involving a sample of 7,512 primary caregivers, the results confirm that the care of dependent people remains a highly feminized task. The increased perception of deterioration of health as a result of providing care among women compared to male caregivers is related to both the greater perception of the responsibility for care and to the characteristics of the care given, which is more intense and focuses more on tasks associated with risks for health ${ }^{29}$.

\section{Guidelines for the inclusion of the gender perspective in health systems}

According to the WHO, the incorporation of the gender analysis should permeate all aspects of public policy. However, it is not a question of considering both sexes equally, but instead of taking biological and social differences and inequalities in terms of roles, resources and power into accoun $^{30}$. According to Villela et al., gender analysis refers "to the construction of a new perspective on women and men which in healthcare enables their needs to be redefined" ${ }^{\prime 31}$. In other words, the issue is one of meeting the specific needs of women and men in order to achieve gender equality ${ }^{30}$ At present, a common objective in all areas of health systems is to promote the inclusion of the gender approach to achieve equality and equity in health, following the recommendations of international organizations.

60th World Health Assembly WHA 60.25 Point 12.12 on the Agenda, 23 May, 2007. Incorporation of gender analysis and actions in WHO activities: a strategy project, following the recommendations of the Programme of Action of the International Conference on Population and Development (Cairo, 1994), the Beijing Declaration and Platform for Action (1995), the recommendations of the Beijing + 10 Conference (2005), the 1997/2 conclusions of the Economic and Social Council, the Millennium Declaration of the United Nations, 2000, the Final Document of the 2005 World Summit, resolution WHA58.30 on accelerating achievement of the internationally agreed health-related development goals, including those contained in the Millennium Declaration.

Of particular interest is the 60th World Health Assembly ${ }^{32}$, which in paragraph 12.12, 
calls on its Member States to adopt the following recommendations:

1. To include gender analysis and planning in joint strategic and operational planning, and budget planning as appropriate, including country cooperation strategies;

2. To formulate national strategies for addressing gender issues in health policies, programmes and research, including in the area of reproductive and sexual health;

3. To lay emphasis on training and sensitization on, and promotion of, gender, women and health.

4. To ensure that a gender-equality perspective is incorporated in all levels of health-care delivery and services, including those for adolescents and youth.

5. To collect and analyse sex-disaggregated data, conduct research on the factors underlying gender disparities, and use the results to inform policies and programmes.

6. To make progress towards gender equality in the health sector, in order to ensure that the contribution of women, men, girls and boys as providers of health care is considered in health policy and planning and training for health-care workers;

Various agencies have developed action plans that include recommendations, practical instructions and theoretical and methodological approaches for the implementation of the gender approach in health. We mention here the guides that focus on gender in healthcare. A description and analysis is presented below.

\section{Guides focusing on the integration of gender in healthcare}

As mentioned in the health-disease process, biological differences clearly interact with social determinants, defining the needs and experiences of women and men. In this case, gender equity may require treatment and care that is qualitatively different and sensitive to these different needs. When there is no biological reason to explain the different results, we must consider that social discrimination may be the prime suspect for these results ${ }^{8}$. In specific terms, guidelines with recommendations have been developed to integrate the gender perspective in health programmes and comprehensive health plans. Lasheras et al. ${ }^{33}$ mention the strategic lines of in- tervention on women's health with a gender approach. They are:

1. The development of healthy policies from the public sector, referring to general policy decisions in all sectors and at all levels of government, characterized by an explicit concern for health and equity, and potential impact in this field. Within this group, we can highlight the following measures:

- To promote an integrated gender approach to laws, programmes, planning and budget allocations.

- To take all necessary measures to eliminate all forms of discrimination against women and girls.

- To eradicate the various ways in which violence against women occurs, promoting the empowerment of women, the participation of women's associations, and the reorientation of health services.

2. The creation of healthy environments, not only physically, but also in terms of social, political and economic dimensions, such as working conditions and health, suitable jobs, monitoring environmental factors that affect the women's health, also involves designing urban measures with a gender approach.

3. The development of personal skills by means of health education. This group includes empowerment, which Marcela Lagarde defines as follows: "Empowerment is created in processes in which each woman strengthens and develops the political capacity that enables her to defend herself, confront oppression and cease to be subject to control. That is the profound sense of individual empowerment, which only occurs if is supported collectively." She adds: "This also means collective gender empowerment, and women's collective ability to confront consciousness and in political alliance, to dismantle the old order and the daily construction of renewed forms of social, economic, political and cultural coexistence" ${ }^{34}$.

4. Reinforcement of community action, COordinating community participation, so that women's associations can access decision-making spheres.

5. Reorientation of health services to introduce changes to ensure fairness, including the training of professionals in the gender approach and access to care ${ }^{32}$.

Velasco points out that promoting the inclusion of the gender approach to achieve equality 
and equity in health is currently a common goal in all areas of health systems, and she considers addressing social and psychosocial vulnerability factors and taking action on health to be equally necessary ${ }^{35}$.

The guides facilitate the inclusion of the gender perspective in Health Plans. This inclusion is necessary since according to the "Guide to facilitate the inclusion of the gender perspective in Comprehensive Health Plans" produced by the Ministry of Health of the Government of Andalusia, there is a predominant and false perception among the various groups of health professionals that technical, health and managerial work, the adjustment of resources, training opportunities, etc., are gender-neutral. Among the conditions mentioned in the guide for inclusion of the gender perspective in healthcare is an explicit commitment to ensuring its implementation in the political and organizational sphere, availability of the resources and means to carry it out, and awareness of the need for its implementation and training to do $\mathrm{so}^{36}$.

Public policies are the result of action by the State, which is responsible for sanctioning the formality that legitimises instruments of expression as public policy. They can be expressed through various types of instruments for their formulation, including laws, regulations, decrees, etc. and even administrative and technical instruments, such as plans, budgets, projects that are approved $^{37}$.

In the next and final section of this paper, we discuss the elements which a public health policy should include within equality policies from a gender perspective.

\section{By way of a proposal: dimensions of the gender perspective in health policies}

Gender is a category of analysis that enables us to analyze the sociocultural construction of the sexes. As we have seen, the relationship of the concept of gender to knowledge of health began to be examined in the 1970s. The importance of this concept has led us to develop a definition of what a health policy with a gender perspective is.

After all the analyses, we define health policy with a gender perspective or gender sensitivity as a policy which in its institutional mechanisms makes women visible and ensures their participation, taking into account the mainstreaming of the gender perspective in the actions and the determining factors in the process of health and disease in relation to sex/gender, and promotes the gender perspective in the research and training of healthcare professionals. Furthermore, including the gender perspective in health policies requires use of non-sexist and non-androcentric language. The aim is to reduce and eliminate social inequalities related to gender.

We propose the following points to implement the gender perspective:

1. Visibility of women. This involves making the reality of women visible and to do so, the first element to be taken into account in public policy with a gender perspective is to make women visible. To give women visibility in relation to their health and problems, all data generated during the process of health policies must be disaggregated by sex.

2. Equal participation. Equal participation should be promoted throughout the design process of certain plans and programs. In particular, parity between women and men must be promoted so that appointments made to management teams, editors, advisory councils and participatory bodies tend towards parity.

3. Non-sexist language and images. Language that makes women and men equally visible must be used in the design of programmes and plans, in both written and visual language.

4. Inclusion of health and/or disease determinants in relation to sex/gender. The risk elements and factors related to sex/gender which are determinants of health and their problems in certain health programmes and plans must be taken into account.

5. Promote mainstreaming. This implies that gender must be present in all general policies and measures and when they are planned, their impact on men and women is taken into account.

6. Gender-sensitive training. Undergraduate and continuous training given to professionals must include the gender perspective in order to avoid bias in professional practice.

7. Gender-sensitive research. The presence of gender in the health/disease process must be researched, and professionals must be guided with regard to the inclusion of gender dimensions in research.

In the health sciences, as in other sciences, gender theory opens up a wide range of possibilities for investigating the causes of the differ- 
ences and inequalities in health problems. Health systems, which are created to meet the health needs of communities, must take into account the knowledge generated by research to alleviate these inequalities, following the guidelines of international organizations. According to Villela et al., "making a broad-based axis in health research entails a commitment to the possibility that the presentation of evidence of health inequalities between men and women, which are the result of gender inequalities, can influence public policy in order to reduce these inequalities"31.

\section{Collaborators}

ML Panisello and I Pastor have participated equally in each stage of the preparation of this article. 


\section{References}

1. Cuaderno CAPS. Mujer y Calidad de Vida. Barcelona: CAPS; 1991.

2. Wilkinson S, Kitzinger C. Mujer y Salud. Barcelona: Paidos; 1996.

3. Valls-Llobet C. La atención de género en la Atención Primaria. Quadern CAPS 1998; 27:46-52.

4. Rohlfs I, Borell C, Fonseca MC. Género, desigualdades y salud pública: conocimientos y desconocimientos. Gaceta Sanitaria 2000; 14(3):60-71.

5. Ruiz-Cantero MT, Verdú-Delgado M. Sesgo de género en el esfuerzo terapéutico. Gaceta Sanitaria 2004; 18(19):118-125.

6. Delgado A. Lopez-Fernandez L. Práctica profesional y género en atención primaria. Gaceta Sanitaria 2004; 18(19):112-117.

7. Whitehead M. The concepts and principles of equity and health. Int J Health Serv 1992; 22(3):429-445.

8. Sen G, George A, Östiln P. Incorporar la perspectiva de género en la equidad en salud: un anàlisis de la investigación y las políticas. Organización Panamericana de la Salud, Harvard Center for population and Development Studies; 2005. [acesado 2011 Oct 26]. Disponible en: http://www.paho.org/Spanish/DD/PUB/PO_14entire_book.pdf

9. Organitzación de Naciones Unidas (ONU). IV Conferencia Mundial de las Naciones Unidas (ONU) sobre las Mujeres que tuvo lugar en Beijing. Washington: ONU; 1995.

10. Organización Mundial de la Salud (OMS). Integración de las perspectivas de género en la labor de la OMS. Ginebra: OMS; 2002.

11. Organización de Naciones Unidas (ONU). Resolución aprobada por la Asamblea General 55/2. Declaración del Milenio. Washington: ONU; 2000.

12. Guzman V. La institucionalidad de género en el estado: Nuevas perspectivas de anàlisis. Santiago de Chile: Unidad Mujer y Desarrollo; 2001.

13. Astelara J. Veinte años de igualdad. Madrid: Cátedra.; 2005.

14. Healy B. The Yentl syndome. N Engl J Med 1991; 325(4):274-276.

15. Valls-Llobet C. El estado de la investigación en salud y género. En: Miqueo C, Tomás C, Tejero C, Barral MJ, Fernandez TY. Perspectivas de género en salud. Fundamentos científicos y socio-profesionales de diferencias sexuales no previstas. Madrid: Minerva; 2001.

16. Subirats MM. Conquistar la igualdad: la coeducación hoy. Organización de Estados Iberoamericanos. Para la Edución, la Ciencia y la Cultura. Revista Iberoamericana de educación. no 6. Género y Educación. Septiembre- Diciembre 1994. [acesado 2012 Abr 14]. Disponíble en: http://www.rieoei.org/oeivirt/rie06a02.htm

17. Rivera Garretas MM. Nombrar el mundo en femenino. Barcelona: ICARIA; 2003

18. Borell C, Rohlfs I, Artazcoz L, Muntaner C. Desigualdades en salud según la clase social en las mujeres. ¿Como influye el tipo de medida de la clase social?. Gaceta $\mathrm{Sa}$ nitaria $2004 ; 18(2): 75-84$.

19. Escribá AV. Trabajar fuera de casa. ¿Mejora la salud de la mujer?. Medicina Clínica 1997; 108:580-581.

20. Artazcoz L, Borell C, Rohlfs I, Beni C, Moncada A, Benach J. Trabajo doméstico, género y salud en población ocupada. Gaceta Sanitaria 2001; 15(2):150-153.
21. Artázcoz L, Borell C, Merino J, García-Calvente MM, Sanchez-Cruz JJ, Ramos JL, Codina AD, León AC, Esnaola S, Ramos JL, Anitua C, Rohlfs I. Desigualdades de género en salud: la conciliación de la vida laboral y familiar. En: Cabasés JM, Villabí JR, Aibar C, editores. Invertir para la salud. Prioridades en salud pública. Valencia: SESPAS; 2002. Informe SESPAS 2002.

22. Torns T, Carrasquer P, Parella S, Recio C. Les dones i el treball a Catalunya: mites $i$ certeses. Barcelona: Institut Català de les Dones, Generalitat de Catalunya; 2007.

23. Borderias MC, Carrasco Bengoa C, Alemany C. Las mujeres y el trabajo. Rupturas conceptuales. Barcelona: Icaria; 1994.

24. Carrasquer P, Torns T, Tejero E, Romero A. El trabajo reproductivo. Papers 1998; 55:95-114.

25. Artazcoz L, Borrell C, Benach J. Gender inequalites in health among workers: the relation with family demands. J Epidemiol Community Health 2001; 55(9): 639-647.

26. Navarro V, Quiroga A. Políticas de Estado de bienestar para la equidad. Gaceta Sanitaria 2004; 18(19):147-157.

27. Instituto de la mujer y para la igualdad de oportunidades. "Mujeres y cifras". [acesado 2014 abr 1]. Disponíble en: http://www.inmujer.gob.es

28. Panisello LM, Lasaga A, Mateu ML. Cuidadores principales de ancianos con demencia que viven en su domicilio. Gerokomos 2000; 11(4):174-178.

29. García Calvente MM, del Rio LM, Marcos JM. Desigualdades de género en el deterioro de la salud como consecuencia del cuidado informal en España. Gaceta Sanitaria 2011; 258(Supl. 9):100-107.

30. Organización Mundial de la Salud (OMS). Gender and health: Technical paper. Geneva: OMS; 1998.

31. Villela W, Monteiro S, Vargas E. A incorporaçao de novos temes e saberes nos estudos em saúde colectiva: o caso do uso de categoria genero. Cien Saude Colet 2009; 14(4):999-1003.

32. Organización Mundial de la Salud (OMS). Incorporación del análisis y acciones de genero en les actividades de la OMS: proyecto de estrategia. Geneva: OMS; 2007.

33. Lasheras ML, Pires M, Rodriguez MM. Género y Salud $n^{\circ}$ 3. Andalucia: Instituto Andaluz de la Mujer; 2004.

34. Lagarde y de los Rios M. Claves feminista para la autoestima de las mujeres. Madrid: Ed Horas y Horas; 2000. (Col. Cuadernos Inacabados, no 39).

35. Velasco S. Recomendaciones para la práctica del enfoque de género en programas de salud. Madrid: Dirección General de la Agencia de Calidad del Sistema Nacional de Salud, Secretaria General de Sanidad. Ministerio de Sanidad y Consumo; 2008. Observatorio de Salud de la Mujer (OSM).

36. Amo Alfonso M. Guía para facilitar la incorporación de la perspectiva de género en los Planes Integrales de Salud. Andalucía: Consejeria de Salud; 2008.

37. Garcia Prince E. Políticas de Igualdad, Equidad y Gender Mainstreaming. ¿De qué estamos hablando?: Marco Conceptual. Programa de Naciones Unidas para el Desarrollo. (PNUD). San Salvador: ONU; 2008.

Article submitted 07/30/2014

Approved 10/09/2014

Final version submitted 10/11/2014 
